'Essays' are now out of date, that we have introduced Science into the schools and got what he asked for. It is not so. In fact, we have only the shadow--not the substance. The teaching, for the most part, is of the kind he abhorred and knew to be useless." "Huxley was undoubtedly a man of very great innate ability, a man who had gained full grasp of the world; he saw very clearly what the needs were, but was no master of method. Cannot men be found to study his great example but go further, especially in developing methods?" Prof. Armstrong said that it is in connexion with medical education that Huxley's instructions have been least regarded. Huxley complained specifically of the unsatisfactory character of the teaching in physiology and asked for a proper scientific foundation at school, followed by a minimum burden during the period of professional training.

HuXLEY's efforts to secure public recognition of the value of scientific education, said Prof. Armstrong, led to the establishment of the City and Guilds of London Institute for the Advancement of Technical Education and of its two colleges, the Finsbury Technical College (1879) and the Central Technical College (1884). The latter is now known as the City and Guilds (Engineering) College, and forms part of the Imperial College of Science and Technology. In an address on "Science and Culture", Huxley defended the thesis that for the purpose of attaining real culture an exclusively scientific education is at least as effectual as an exclusively literary education-to which Prof. Armstrong replies that he does not believe that either in itself can give us culture or is, in fact, possible exclusively. "The world insists on teaching a good deal, however much the schools may fail to teach." But Huxley made an important recommendation : that provision should be made for teaching sociology. Already in 1887 he foresaw the coming gravity of our industrial position, and wrote a remarkable letter to the Times. He called upon the nation to 'organise victory', and Prof. Armstrong echoed his words. A nation of shopkeepers, we have, he says, worshipped technical education; unfortunately, it has not taught us to keep shop: only to make things to be sold but not how to sell them, to the general good, when made. The problem of food looms in full face of a present need; that our food supply must be our first care is as yet realised by few. We can no longer allow uncontrolled use of the soil. We must learn how to use our knowledge. Scientific workers must bestir themselves to educate the public, even as Prof. Armstrong educates while he castigates.

\section{New Medals of the Royal Aeronautical Society}

Two new medals have been founded by the Royal Aeronautical Society, to be known as the British Gold Medal for Aeronautics and the British Silver Medal for Aeronautics. These medals have been founded following a request from Lord Amulree, when Secretary of State for Air, that the Royal Aeronautical Society should give some award for outstanding feats in aviation. A permanent Committee has been appointed to consider the awards of the medals, consisting of six members of the Royal Aeronautical Society, and the chairmen of the Royal Aero Club and the Air League of the British Empire. The design of the Gold Medal incorporates a portrait of Sir George Cayley and his first model aeroplane of 1804, and the design of the Silver Medal incorporates the Henson and Stringfellow machines. The medals will be awarded for an achievement leading to advancement in aeronautical science and will be confined, so far as possible, to subjects of the British Empire, but other nationals will not be excluded. The expenses of founding these two medals have been defrayed by the president, Mr. C. R. Fairey. The first awards of the British Silver Medal for Aeronautics have been made for the following achievements which have led to advances in aeronautical science: Capt. C. F. Uwins, for reaching a world record height in a heavier-than-air craft of $43,976 \mathrm{ft}$. on September 16, 1932 ; Squadron Leader O. R. Gayford, and Flight-Lieut. G. E. Nicholetts, who flew from Cranwell, England, to Walvis Bay, South Africa, non-stop on February 6-8, 1933, a distance of 5,340 miles.

\section{Excavations in Northern Mesopotamia}

EXPECTATION of the importance of the results likely to be obtained by the joint expedition of the British Museum and the British School of Archæology in Iraq to Tell Arpachiyah in northern Mesopotamia under Mr. M. E. L. Mallowan is fully confirmed by the report of the first half season's work which appears in the Times of May 5. The expedition left London in January. It will be remembered that this site was selected for excavation as the result of a preliminary reconnaissance from Nineveh in the previous year. Surface finds of painted potsherds then suggested that this site would probably prove of great importance to the little-known earlier prehistory of northern Mesopotamia. The discovery of pottery of the Ur and Tell el-Ubaid type in mud-brick dwellings of a humble character on the top of the mound carries the first settlement well back into the fifth millennium B.c., and proves the site to be among the oldest yet discovered in Mesopotamia. As excavation proceeds, Arpachiyah is shown to be the centre of convergence for peoples transitional between neolithic and chalcolithic times; while connexions are being traced with Anatolia, Syria, southern Mesopotamia and, through Persia, with Baluchistan. It may be noted, in passing, that Arpachiyah supports and extends the evidence obtained by the American School of Oriental Research at Tepe Gawra and Tell Billa that northern Mesopotamia was a place of settlement for peoples from the north and north-east, who were there subjected to strong cultural influences from the south. Among the more noteworthy discoveries now reported at Arpachiyah are a method of fractional burial which is compared with the practice on the prehistoric site of Nal in Baluchistan, the use of a bucranium or ox's head as a motif to an extent which suggests a special cult, 